\title{
Neck Soft Tissue Necrotic Lesion
}

National Cancer Institute

\section{Source}

National Cancer Institute. Neck Soft Tissue Necrotic Lesion. NCI Thesaurus. Code C78502.

A necrotic process affecting the soft tissues of the neck. 